\title{
Sentralisasi Kewenangan Perizinan Usaha oleh Pemerintah Pusat dalam Rancangan Undang - Undang Mineral dan Batubara
}

\author{
Roni Sulistyanto Luhukay dan Rachmasari Kusuma Dewi
}

Fakultas Hukum Universitas Widya Mataram

E-mail: roni.luhukay@yahoo.com

\begin{abstract}
Abstrak
Rancangan Undang - Undang (RUU) mineral dan batubara mineral dan batubara ini bermaksud untuk memangkas birokrasi yang berbelit - belit dan bermaksud untuk menyelesaikan persoalan hiper-regulasi yang terjadi di Indonesia. RUU mineral dan batubara yang mengatur sentralisasi perizinan dimana perizinan mutlak menjadi kewenangan pemerintah pusat bertentangan dengan prinsip Lex Superior derogat Legi Inferior, dapat dilihat dari amanah Pasal 18 Undang - Undang Dasar Negara Republik Indonesia Tahun 1945, yang merupakan landasan yang kuat untuk menyelenggarakan sistem desentralisasi atau Otonomi Daerah. Penelitian ini menggunakan metode penelitian yuridis normatif yang mengkaji mengenai problematika yang muncul dengan adanya ketidakkepercayaan pemerintah pusat terhadap pemerintah daerah Kabupaten/Kota serta rendahnya jaminan kepastian investasi untuk investor. Perubahan dalam sistem tatanan Pelaksanaan Sistem Perizinan yang sentralistik dengan tidak dilibatkanya pemerintah provinsi atau kabupaten/kota akan memberikan dampak tidak adanya pengawasan kegiatan usaha, keterlambatan pengaturan. Tata laksana pengaturan Undang - Undang yang menyangkut kewenangan Gubernur dan Bupati/Walikota menjadi tidak berfungsi karena meletakan kewenangan sepenuhnya kepada pemerintah pusat.

Kata Kunci: Sentralisasi, Perizinan, RUU Mineral dan Batubara
\end{abstract}

\begin{abstract}
This draft mineral and coal coal law intends to cut the complicated bureaucracy and intends to solve the hyper-regulation problems that occur in Indonesia. The draft mineral and coal law governing licensing centralization in which absolute licensing is the authority of the central government is contrary to the principle of Lex Superior derogat Legi Inferior, can be seen from the mandate of Article 18 of the 1945 Constitution of the Republic of Indonesia, which is a strong foundation for conducting decentralized system or Regional Autonomy. This study uses a normative juridical research method that examines the problems that arise with the lack of trust of the central government towards district / city governments and the low guarantee of investment certainty for investors. Changes in the order system Implementation of a centralized licensing system with no involvement of provincial or district governments will have the effect of not overseeing business activities, delays in regulating or reducing the local tax on which the business is run. The administrative procedures in the Law concerning the authority of the governor and
\end{abstract}


regent / mayor become dysfunctional because they place full authority on the central government.

Keywords: Centralization, Licensing, Mineral and Coal Bill

\section{A. Pendahuluan}

Undang - Undang Dasar Negara Republik Indonesia Tahun 1945 merupakan dasar hukum tertinggi di Indonesia. Dalam tataran normatif, UUD NRI 1945 dianggap sebagai norma hukum tertinggi (the supreme law of the land) dalam sistem hierarki norma hukum di Indonesia. Pernyataan ini mengandung makna bahwa konstitusi tersebut memiliki derajat yang paling tinggi dibandingkan dengan bentuk peraturan perundang-undangan lain. Sedangkan dalam tataran praktis, posisi konstitusi sebagai hukum tertinggi bermakna bahwa segenap elemen bangsa, baik penyelenggara negara maupun warga negara dalam menunaikan tugasnya menyelenggarakan kehidupan berbangsa dan bernegara, haruslah mengacu dan merujuk pada konstitusi. Keberadaan negara Indonesia sebagai negara hukum harus di buktikan dengan eksisnya lembaga-lembaga kekuasaan negara,dimana landasar tertinggi di tuangkan dalam UUD NRI 1945, pengaturan suatu negara diatur dalamnya. Pengaturan desentralisasi diatur dalam UUD NRI 1945 pasal 18. ${ }^{1}$ Pengaturan perizinan yang setralisasi dapat menimbulkan kekacouan hukum serta tindakan sewenang-wenang. ${ }^{2}$ Hal ini dapat dilihat pada masa orde baru adanya kewenangan yang sentralisasi membuat tidak adanya pemerataan pembagunan serta banyaknya kasus pelanggaran HAM dari tindakan sewenang wenang pemerintah Pusat. Desentralisasi dan otonomi daerah adalah suatu peristiwa yang menimbulkan perubahan mendasar pada hubungan antara pemerintah pusat dan pemerintah daerah. Hubungan yang dulunya sentralistik telah

\footnotetext{
${ }^{1}$ Roni Sulistyanto Luhukay, "Indenpendensi Kekuasaan Kehakiman Pasca Amandemen UUD 1945 dan Relevansinya Bagi Penegakan Hukum Berkeadilan”, Jurnal Jurisprudentie, Vol. 6, No. 1, Juni, 2019, hlm. 136.

${ }^{2}$ Roni Sulistyanto Luhukay, "Karakteristik Tanggung Gugat Perusahaan Terhadap Lingkungan Dalam Menciptakan Kesejateraan Rakyat”, Junal Meta Yuridis, Vol. 2, No. 1, 2009, hlm. 26.
} 
berubah menjadi desentralistik yang ditandai dengan pemberian otonom yang luas dan nyata kepada daerah. ${ }^{3}$

Sistem pemerintahan daerah di Indonesia menurut konstitusi Undang Undang Dasar Negara Republik Indonesia Tahun 1945, berdasarkan penjelasan dari Pasal 18 ayat (1) tersebut dinyatakan bahwa daerah Indonesia adi bagi dalam daerah Provinsi dan daerah Provinsi di bagi lagi menjadi daerah yang lebih kecil. ${ }^{4}$ Pasal 2 Angka 1 Undang - Undang Nomor 23 Tahun 2014 tentang Pemerintahan Daerah yang mengatur lebih jelas mengenai pembagian wilayah negara antara lain sebagai berikut: Negara Kesatuan Republik Indonesia dibagi atas daerah Provinsi dan daerah Provinsi itu dibagi atas daerah Kabupaten dan Kota dan daerah Kabupaten/Kota dibagi atas Kecamatan dan Kecamatan dibagi atas kelurahan dan/atau Desa. Desentralisasi ini dilakukan sebagai bagian memberikan kepercayan kepada pemerintah daerah untuk dapat mengembangakan daerah dan secara filosofis mendekatkan pelayanan kepada masyarakat.

Berdasarkan Undang - Undang Dasar Negara Republik Indonesia tahun 1945, yang merupakan landasan yang kuat untuk menyelenggarakan Otonomi Daerah. Pasal 18 Undang - Undang Dasar Negara Republik Indonesia tahun 1945, menyebutkan adanya pembagian pengelolaan pemerintahan pusat dan daerah. Sistem otonomi daerah dituangkan dalam Pasal 18 ayat (2) yang menyebutkan, bahwa Pemerintahan daerah Provinsi, daerah Kabupaten, dan Kota mengatur dan mengurus sendiri urusan pemerintahan menurut asas otonomi dan tugas pembantuan.” Selanjutnya, pada ayat (5) tertulis, "Pemerintahan daerah menjalankan otonomi seluas-luasnya kecuali urusan pemerintahan yang oleh Undang-Undang ditentukan sebagai

${ }^{3}$ Lukman Santoso Az, 2015, Hukum Pemerintahan Daerah Mengurai Problemetika Pemekaran Daerah Pasca Reformasi di Indonesia, Pustaka Pelajar, Yogyakarta, hlm. 1.

${ }^{4}$ Siswanto Sunarno, 2006, Hukum Pemerintahan Daerah di Indonesia, Sinar Grafika, Jakarta, hlm 1. 
urusan pemerintah pusat." Ayat (6) menyatakan "Pemerintahan daerah berhak menetapkan peraturan daerah dan peraturan-peraturan lain untuk melaksanakan otonomi dan tugas pembantuan" dengan tetap berpeoman pada konsep negara keastuan yang tidak menciptakan negara di dalam negara dengan tidak menciptakan kewenanagan asli.

Otonomi daerah memberikan kemungkinan yang besar untuk lebih baiknya pengelolaan perizinan kegiatan usaha khususnya kegiatan usaha yang berkaitan dengan lingkungan. Hal ini disebabkan karena kebijakan dan keputusan yang berkaitan dengan permasalahan dampak terhadap pengelolaan izin usaha akan lebih diandalkan karena melibatkan partisipasi pemerintah daerah. Demikian pula dengan kontrol dari pemerintah daerah dalam berbagai kelompok kepentingan di daerah akan berjalan secara langsung dan cepat. ${ }^{5}$

Berdasarkan pada suatu otonomi daerah pada prinsipnya bertujuan untuk mendekatkan proses pengambilan keputusan kepada masyarakat, sehingga kebijakan publik dapat lebih diterima dan produktif dalam memenuhi kesejahteraan dalam keadilan maka dengan bidang lingkungan hidup otonomi daerah seharusnya bermakna sebagai: ${ }^{6}$

a) Penyesuaian kebijakan pengelolaan sumber daya alam lingkungan yang sesuai dengan ekosistem setempat.

b) Menghormati kearifan adat masyarakat yang sudah dikembangkan masyarakat.

c) Mengelola daya dukung lingkungan setempat dan menjahui cara - cara yang dapat menghancurkan ekosistem dengan eksploitasi yang berlebihan.

${ }^{5}$ Roni Sulistyanto Luhukay, “Tanggung Jawab PT Freeport Indonesia terhadap Penanganan Kerusakan Lingkungan Akibat Pertambangan di Kabupaten Mimika Papua”, Lex Et Societatis, Vol. IV, No. 2, Maret, 2016, hlm. 1.

${ }^{6}$ Siswanto Sunarno, Op.Cit., hlm. 249-250. 
d) Tumbuhnya ketertiban secara aktif masyarakat dan penduduk setempat sebagai pihak yang paling berkepentingan dalam pembuatan kebijakan pengelolaan sumber daya alam dan lingkungan hidup.

e) Semakin diperlukannya kesadaran mengenai adanya kesatuan ekologi diantara pemerintah daerah yang batas wilayahnya cenderung di dasarkan pada batas administratif.

UU Pemerintah Daerah mengatur mengenai perizinan IUP yang memberikan kewenangan pemerintah pusat kepada pemerintah provinsi, akan tetapi dalam RUU Mineral dan Batubara, kewenangan ditarik ke pemerintah pusat di bawah kekuasaan Presiden dengan maksud untuk memangkas sistem birokrasi.

Rancangan sentralisasi dalam perizinan usaha menimbulkan permasalahan hukum baru khususnya dalam perubahan di sektor Energi dan Sumber Daya Mineral (ESDM). Permasalahan ini meliputi Pasal 40 terkait dengan perubahan UU Nomor 4 Tahun 2009 tentang Mineral dan Batubara (Minerba). Salah satu yang menjadi sorotan adalah terkait dengan kewenangan pemerintah daerah (Pemda) dalam perizinan dan pengelolaan tambang minerba diambil alih oleh pemerintah pusat. Hal ini dapat dilihat dengan dihapuskannya Pasal 7, Pasal 8, dan Pasal 37 dalam UU Minerba. Pasal 7 UU Minerba menerangkan tentang kewenangan pemerintah provinsi (pemprov) dalam pengelolaan pertambangan minerba. Pasal 8 mengatur tentang kewenangan pemerintah kabupaten (pemkab) atau pemerintah kota (pemkot) dalam pengelolaan pertambangan minerba. Sedangkan Pasal 37 mengatur pemberian Izin Usaha Pertambangan (IUP). Pasal 37 UU Minerba, IUP diberikan oleh: (a) bupati/walikota apabila Wilayah IUP (WIUP) berada dalam satu wilayah kabupaten/kota; (b) gubernur apabila WIUP berada dalam lintas wilayah kabupaten/kota dalam satu provinsi setelah mendapatkan rekomendasi dari Bupati/Walikota setempat; dan (c) menteri, apabila WIUP berada pada lintas 
wilayah provinsi setelah mendapatkan rekomendasi dari gubernur dan bupati/walikota setempat. Ahmad Redi seorang Pengamat pertambangan dari Universitas Tarumanegara yang sekaligus sebagai Tim Perumus Omnibus Law menyatakan bahwa pelimpahan kewenangan itu dimaksudkan untuk memutus rantai birokrasi yang berbelit - belit. Selain itu, penerapan perizinan usaha di omnibus law dilakukan dengan berbasis pada risiko perizinan di omnibus law cipta kerja diatur ke dalam tiga skala dengan mempertimbangkan risiko, yakni berisiko tinggi (high risk), sedang (middle risk) dan rendah (low risk). Segala bidang usaha yang high risk diwajibkan memiliki izin usaha. Sedangkan bidang usaha middle risk wajib menerapkan standar, dan untuk low risk cukup registrasi untuk mendapatkan Nomor Induk Berusaha (NIB).

RUU pengaturan mineral dan batubara menjadi polemik hingga hari ini karena dianggap melanggar prinsip konstitusionalisme. Undang-Undang ini dianggap melanggar prinsip konstitusionalisme, karena melanggar semangat keselarasan hukum, dalam arti memicu terjadinya pertentangan antar peraturan perundang-undangan. Selain itu, RUU ini dianggap bertentangan dengan berbagai prinsip dasar yang diatur di dalam konstitusi itu sendiri. Rancangan undang undang bertentangan prinsip hukum Lex Superior derogat Legi Inferior (peraturan perundang-undangan yang lebih tinggi mengesampingkan peraturan perundang-undangan yang lebih rendah).

RUU yang mengatur sentralisasi kewenangan bertentangan dengan UUD NRI Tahun 1945, yang merupakan landasan yang kuat untuk menyelenggarakan Otonomi Daerah. Pasal 18 UUD NRI Tahun 1945, menyebutkan adanya pembagian pengelolaan pemerintahan pusat dan daerah. Konsep desentralisasi perlu dilakukan sebagai bagian untuk mencegah obesistas hukum yang dilakukan oleh pemerintah pusat dikarenakan makna yang menjadi objek adalah, ketepatan atau pelaksanaan sesuai dengan tujuan 
dan sarana yang digunakan untuk mencapai tujuan ${ }^{7}$, obesitas hukum yang dimaksudkan di sini adalah kelebihan pengaturan regulasi yang tidak sesuai dengan amanah UUD NRI 1945 serta secara filosofisi kurang efisien serta kelebihan regulasi ini melanggar semangat keselarasan hukum.

\section{B. Metode Penelitian}

Penelitian ini merupakan penelitian hukum dengan mengunakan metode hukum normatif. Menurut Philipus M Hadjon dan Tatiek Sri Djatmiati penelitian hukum normatif beranjak dari hakekat keilmuan hukum ${ }^{8}$. Sejalan dengan itu Peter Mahmud Marzuki mengemukan Legal Research adalah penelitian hukum yang mengunakan pendekatan, pendekatan perundang undangan (Statute Aprroach), pendekatan konseptual (Conceptual Approach). ${ }^{9}$

Penulis menjelaskan mengenai pendekatan perundang - undangan (Statute Aprroach) dalam pembahasan pertama. Penulis perlu memahami hierarki, dan asas - asas dalam peraturan perundang - undangan. Menurut Pasal 1 angka 2 Undang - Undang Nomor 12 Tahun 2011, peraturan perundang - undangan adalah peraturan tertulis yang memuat norma hukum yang mengikat secara umum dan dibentuk atau ditetapkan oleh lembaga Negara atau pejabat yang berwenang melalui prosedur yang ditetapkan dalam peraturan perundang - undangan. Dari pengertian tersebut, secara singkat dapat dikatakan bahwa yang dimaksud sebagai statute berupa legislasi dan regulasi. Jika demikian, pendekatan peraturan perundang - undangan adalah pendekatan dengan menggunakan legislasi dan regulasi. ${ }^{10}$ Pembahasan kedua penulis menjelaskan mengenai pendekatan konseptual (Conceptual Aprroach),

\footnotetext{
${ }^{7}$ Roni Sulistyanto Luhukay dan Abdul Kodir Jailani, "Penataan Sistem Peraturan Perundang-Undangan Dalam Mendukung Pengutan Konstitusi Ekonomi Indonesia", Jurnal Jatiswara, Vol. 34, No. 2, Juli, 2019, hlm. 158.

${ }^{8}$ Philipus M Hadjon dan Tatiek Sri Djatmiati, 2016, Argumen Hukum, Gadjah Mada University Press, Yogyakarta, Cet. VII, hlm. 3.

${ }^{9}$ Johnny Ibrahim, 2010, Teori dan Metodologi Penelitian Hukum Normatif, Banyumedia, Malang, hlm. 93.

${ }^{10}$ Peter Mahmud Marzuki, 2005, Penelitian Hukum, Edisi Revisi, Kencana, Jakarta, hlm. 136.
} 
pendekatan konseptual dilakukan manakala peneliti tidak beranjak dari aturan hukum yang ada. Hal itu dilakukan karena memang belum atau tidak ada aturan hukum untuk masalah yang dihadapi. Dalam membangun konsep hukum dengan beranjak dari pandangan - pandangan dan doktrin - doktrin yang berkembang di dalam ilmu hukum. ${ }^{11}$

\section{Pembahasan}

\section{Konsep Sentralisasi Perizinan Usaha Di Tinjau Dalam Perspektif Konstitusi}

N.M Spelt dan J.B.J.M Ten Berge izin dalam istilah di bagi menjadi 2 antara lain dalam arti sempit disebut izin sedangkan izin dalam arti luas yang berarti perizinan ialah suatu persetujuan dari penguasa berdasarakan undangundang dan peraturan pemerintah dalam keadaan tertentu dari ketentuanketentuan perundang-undanganan. Lebih lanjut dibedakan dengan bentuk perizinan yang dikemukan oleh Tatiek Sri Djatmiati mengemukakan bahwa perizinan dapat berupa pendaftaran, rekomendasi, sertifikat, menentukan kuato dan izin untuk melakukan kegiatan usaha. A.M Doneer menyatakan perizinan (vergununningen) yang dibedakan menjadi tiga kategori yaitu lisensi, dispensasi dan konsentrasi ${ }^{\mathbf{1 2}}$.

Pengaturan, penerbitan, pelaksanaan dan penegakan hukum terhadap perizinan sebagai sarana untuk melindungi dan menjaga kelestarian dari kegiatan pengelolaan serta dampaknya terhadap lingkungan harus mengimplementasikan prinsip tata kelola pemerintahan yang baik sebagai

\footnotetext{
${ }^{11}$ Ibid., hlm. 177.
}

${ }^{12}$ N.M Spelt dan J.B.J.M Ten Berge, Pengantar Hukum Perizinan, disunting oleh Philipus M Hadjon, 1993, Yuridika, Surabaya, hlm. 1-2. 
standart bagi pemerintah terhadap Pemanfaatan ${ }^{13}$. Tujuan perizinan menurut Prajudi Atmosudirjo yang secara umum dapat diuraikan sebagai berikut:

1. Keinginan mengarahkan ( mengendalikan “sturen”) aktivitas aktivitas tertentu.

2. Izin mencegah bahaya dari lingkungan

3. Keinginan-keinginan melindungi objek tertentu.

4. Izin hendak membagi bagi benda yang sedikit.

5. Izin memberikan pengarahan dengan menyeleksi orang-orang dan aktivitasaktivitas ${ }^{14}$.

Kewenangan pemerintah dituangkan dalam UUD NRI 1945 serta diatur lebih lanjut dalam berbagai ketentuan perundang - undangan. Konstitusi digunakan untuk melukiskan selurus sistem pemerintahan suatu negara, kumpulan peraturan yang mengatur dalam suatu pemerintahan. ${ }^{15}$ Konstitusi UUD NRI Tahun 1945, yang merupakan landasan yang kuat untuk menyelenggarakan sistem desentralisasi atau Otonomi Daerah. Pasal 18 UUD NRI Tahun 1945, menyebutkan adanya pembagian pengelolaan pemerintahan pusat dan daerah. Otonomi daerah diuraikan dalam Pasal 18 ayat (2) dan ayat (5). Selanjutnya, Ayat (6) menyatakan "Pemerintahan daerah berhak menetapkan peraturan daerah dan peraturan-peraturan lain untuk melaksanakan otonomi dan tugas pembantuan."

UU Pemerintah Daerah, menjelaskan bahwa kewenangan perizinan yang dilakukan oleh pemerintah kabupaten/kota dialihkan kepada pemerinah provinsi. RUU mineral dan batubara kewenangan ditarik ke pemerintah pusat

${ }^{13}$ Lilik Pudjiastuti, 2013, Prinsip Hukum Pengaturan Perizinan Kefarmasian, Disertasi, Fakultas Hukum, Universitas Airlangga, hlm. 25.

${ }^{14}$ Prajudi Atmosudirjo, 1983, Hukum Administrasi Negara, Ghalia Indonesia, Jakarta, hlm. 96.

${ }^{15}$ K.C Wheare F.B.A, 1975, Modern Constitution, Oxford University Pers, London, hlm. 1. 
hal ini dikarenakan dengan maksud untuk memangkas sistem birokrasi, yang kemudian alasan ini sangat tidak relevan dikarenakan dengan sistem desentralisasi yang meletakkan kewenangan sebesar - besarnya diberikan kepada pemerintah daerah yang kemudian jika alasan sistem birokrasi seyogyannya memberikan kewenangan pemerintah daerah. Hal ini menunjukan adanya ketidakpercayaan pemerintah pusat kepada pemerintah daerah terkait dengan sistem perizinan yang dilakukan hingga saat ini.

Makna yang terlihat dari UU Pemerintah Daerah di atas jelas bahwa desentralisasi memberikan ruang terjadinya penyerahan kewenangan atau urusan dari pemerintah pusat kepada pemerintah daerah. Otonomi hanya ada kalau ada penyerahan urusan pemerintah kepada daerah. ${ }^{16}$ Esensi desentralisasi adalah proses pengotonomian di mana proses penyerahan kepada satuan pemerintahan yang lebih rendah untuk mengatur dan mengelola urusan pemerintahan tertentu sebagai urusan rumah tangganya, dengan kata lain desentralisasi dan otonomi dua sisi dalam satu mata uang. ${ }^{17}$

Otonomi daerah memberikan kemungkinan yang besar untuk lebih baiknya pengelolaan lingkungan hidup khususnya di dalam bidang perizinan. Hal ini disebabkan karena kebijakan dan keputusan yang berkaitan dengan permasalahan perizinan lingkungan akan lebih efisien serta seyogyannya melibatkan pemerintah daerah sebagai bagian daripada perpanjangan tangan pemerintah pusat kepada daerah serta mendekatkan pelayanan public. Demikian pula dengan kontrol dari pemerintah daerah dalam berbagai kelompok kepentingan di daerah akan berjalan secara langsung dan cepat.

${ }^{16}$ Agussalim Andi Gadjong, 2007, Pemerintahan Daerah Kajian Politik dan Hukum, Penerbit Ghalia Indonesia, Bogor, hlm. 88.

${ }^{17}$ Sirajudin dan Winardi, 2015, Dasar - Dasar Hukum Tata Negara, Setara Pers, Malang, hlm. 332 . 
Dalam hal ini diharapkan pula bahwa kepentingan masyarakat lokal akan dapat terakomodasi.

Pada prinsipnya proses pengambilan keputusan akan lebih baik mengingat pemerintah daerah yang mengetahui secara detai daerahnnya sehingga kebijakan publik dapat lebih diterima dan produktif dalam memenuhi kesejahteraan dalam keadilan, maka dengan bidang lingkungan hidup otonomi daerah seharusnya bermakna sebagai:

a) Penyesuaian kebijakan pengelolaan sumber daya alam lingkungan yang sesuai dengan ekosistem setempat.

b) Menghormati kearifan adat masyarakat yang sudah di kembangkan masyarakat.

c) Mengelola daya dukung lingkungan setempat dan menjahui cara- cara yang dapat menghancurkan ekosistem dengan eksploitasi yang berlebihan.

d) Tumbuhnya ketertiban secara aktif masyarakat dan penduduk setempat sebagai pihak yang paling berkepentingan dalam pembuatan kebijakan pengelolaan sumber daya alam dan lingkungan hidup.

e) Semakin di perlukannya kesadaran mengenai adanya kesatuan ekologi diantara pemerintah daerah yang batas wilayahnya cenderung di dasarkan pada batas administratif. ${ }^{18}$

RUU Mineral dan Batubara yang mengatur sentralisasi perizinan dimana perizinan mutlak menjadi kewenangan pemerintah pusat ini jelas bertentangan dengan prinsip Lex Superior derogat Legi Inferior, dimana prinsip ini menyatakan bahwa setiap peraturan perundang-undangan yang lebih tinggi mengesampingkan peraturan perundang-undangan yang lebih rendah. Prinsip ini dituangkan juga di dalam Penjelasan Undang - Undang Nomor 12

${ }^{18}$ Sunarno Siswanto, Op.Cit, hlm. 249 - 250. 
Tahun 2011 tentang Pembentukan Peraturan Perundang-Undangan, yang menyatakan:

Dalam ketentuan ini yang dimaksud dengan "hierarki" adalah penjenjangan setiap jenis Peraturan Perundang-undangan yang didasarkan pada asas bahwa Peraturan Perundang-undangan yang lebih rendah tidak boleh bertentangan dengan Peraturan Perundangundangan yang lebih tinggi.

Per definisi, Peraturan Pemerintah tidak boleh bertentangan dengan undang-undang karena posisinya yang hierarkhis. Namun prinsip ini dihilangkan oleh RUU mineral dan batubara. Alasan ini yang membuat RUU mineral dan batubara tidak dapat diterima dan mendapatkan penolakan di tengah masyarakat dapat dilihat dengan adanya aksi penolakan dari berbagai kalangan yang melibatkan 2000 orang yang mengelar sidang rakyat menuntut pembatalan RUU minerba,${ }^{\mathbf{1 9}}$ alasan tersebut meliputi tidak adanya transparansi dan terkesan terburuh buruh dalam pembentukan RUU serta adanya ketakutan masyarakat dengan adanya sistem sentralisasi perizinan akan mengembalikan masa orde baru serta katakutan akan terjadinya kemunduran dalam bengaturan birokrasi di Indonesia. RUU ini bermaksud untuk memangkas birokrasi yang berbelit-belit dan bermaksud untuk menyelesaikan persoalan hiper-regulasi yang terjadi di Indonesia. Undang-undang ini bermaksud untuk menghapus berbagai undang-undang yang memberikan kewenangan terhadap pemerintah daerah dalam menentukan pengelolaan alam yang ada di daerah, dan menggantinya dengan undang-undang yang bersifat sentralistik dengan alasan merupakan agenda pembangunan nasional. Upaya pemerintah untuk mengurangi kompleksitas birokrasi peraturan merupakan langkah yang revolusioner. Sejak tahun 2012, The Organization for Economic Co-operation

\footnotetext{
${ }^{19}$ Kumparan, Dua Ribu Orang Gelar Sidang Rakyat, Tuntut Pembatalan UU Menerba, http://M.Kumparan.Com/Kumparannews/2-Ribu-Orang-Gelar-Sidang-Rakyat-Tuntut-PembatalanUu-Minerba-1tvivvmc0ih, diakses tanggal 15 Juni 2020.
} 
and development (OECD) telah menerbitkan laporan kajian mengenai reformasi regulasi di Indonesia. OECD menyatakan: "Indonesia does not, however, have an explicit whole of goverment policy to ensure quality in regulation and regulatory management."20 Sehingga permasalahan ini merupakan suatu permasalahan yang telah lama terjadi kalangan pemerintah, dan tidak ada upaya yang terstruktur untuk mengatasinya. Namun, apabila upaya tersebut dilakukan dengan cara membentuk undang-undang yang meletakan kewenangan yang setralistik yang mengubah seluruh undangundang, maka upaya tersebut adalah upaya yang tidak tepat. Hal ini melanggar semangat keselarasan konstitusi serta sistem sentralisasi perizinan akan mengembalikan masa orde baru serta katakutan akan terjadinya kemunduran dalam bengaturan birokrasi di Indonesia.

\section{Problematika Sentralisasi Kewenangan Perizinan Usaha oleh}

\section{Pemerintah Pusat dalam Rancangan Undang - Undang Mineral dan Batubara}

Pembentukan RUU Mineral dan Batubara mengeni Undang - Undang Penanama Modal memberikan jaminan investasi dan pemberian kewenagan kepada pemerintah pusat untuk melakukan proses perizinan pelimpahan kewenangan itu dimaksudkan untuk memutus rantai birokrasi yang berbelitbelit yang selama ini terjadi. Pemerintah telah menargetkan pertumbuhan ekonomi yang tumbuh rata rata 6 (enam) persen dalam 5 (lima) tahun dan pertumbuhan Produk Domestik Bruto (PDB) per kapita sebesar 4 (empat) +/1 (satu) persen. Namun, pada kondisi saat ini, Indonesia menghadapi tantangan tantangan yang besar, baik yang bersumber dari eksternal maupun

${ }^{20}$ OECD, 2012, Reviews of Regulatory Reform, Government Capacity to Assure High Quality Regulation, OECD, hlm. 19. 
internal. Tantangan eksternal dipicu dari kondisi perekonomian global yang kini tengah mengalami pelemahan dan ketidakpastian. ${ }^{21}$

Dengan adanya pemberian kewenangan yang setralisasi menimbulkan tatatan atau problematika yang yang harus diselesaikan berkaitan masalah otonomi daerah yang diamankan dalam konstitusi kepada pemerintah daerah. Bertolak dari pembangunan semangat birokrasi yang kemudian dibangun oleh undang-undang mineral dan batubara maka sangat berpotensi menciptakan suatu pemerintahan yang superior (pemerintah pusat) dengan meletakan pemerintahan inferior (pemerintah daerah) yang kemudian lembaga inferior tidak memiliki kewenangan dalam pembangunan daerahnya serta hal ini menimbulkan adanya ketidak percayan pemerintah pusat kepada pemerintah daerah dalam pembangunan sistem desentralisai yang kemudian diamanakah oleh undang undang dasar NRI tahun 1945.

Jika bertolak mengenai dari sejarah penerapan penanaman modal yang sentral dengan menggunakan sistem satu atap atau satu pintu sebelumnya sudah pernah diterapkan dalam masa pemerintahan Megawati Sukarnoputri. Akan tetapi, hal ini tidak membuahkan hasil dan problematika investasi masih tetap sama dengan hal yang sebelumnya. Terlepas dari ini semua bahwa invertasi yang dilakukan dengan sistem sentralisasi sangat tidak relevan jika dikaitan dengan kondisi saat ini hal ini dikarenakan tidak sesuai dengan amanah konstitusi.

Beranjak dari ketentuan Pasal 18 UUD NRI Tahun 1945 tersebut, nampak bahwa Negara Indonesia sebagai negara kesatuan menganut asas desentralisasi dalam penyelenggaraan pemerintahan dengan memberi

\footnotetext{
${ }^{21}$ Roni Sulistyanto Luhukay, "Fungsi Rancangan Undang - Undang Omnibus Law Cipta Lapangan Kerja dalam Percepatan Pertumbuhan Ekonomi”, Jurnal Meta Yuridis, Vol. 3, No. 1, 2020.
} 
kesempatan dan kekuasaan kepada daerah untuk menyelenggarakan otonomi daerah. Dalam Negara kesatuan pembagian kewenangan secara vertikal merupakan pembagian kewenagan pemerintahan, antara pemerintah pusat dengan pemerintah daerah. Pembagian wewenang pemerintahan tersebut dapat dilakukan dengan cara atribusi maupun delegasi. Dalam sistem penyelenggaraan pemerintahan negara yang menganut prinsip pemencaran kewenagan secara vertikal, dikenal istilah desentralisasi yakni membagi kewenangan kepada pemerintah bawahan dalam bentuk penyerahan kewenagan. Prinsip ini melahirkan model pemerintah daerah yang menghendaki adanya otonomi dalam penyelenggaraan kewenangan.

Menurut Maurice Duverger, Desentralisasi merupakan penyerahan atau pengakuan hak atas kewenagan untuk mengurus rumah tangga daerah sendiri, atau melakukan suatu kebijakan sendiri. Pengakuan tersebut merupakan suatu bentuk partisipasi rakyat dalam pengambilan keputusan yang merupakan ciri dari Negara Demokrasi. ${ }^{22}$ Menurut Armin, Desentralisasi adalah pendelegasian wewenang dalam membuat keputusan dan kebijakan kepada manajer atau orang-orang pada level bawah pada suatu organisasi. ${ }^{23}$ Ten Berge berpendapat Desentralisasi sebagai suatu penyerahan atau pengakuan hak (mengenai keadaan yang telah dinyatakan) atas kewenangan untuk pengaturan dan Pemerintahan dari badan-badan hukum publik yang rendahan atau organ-organ, dalam hal ini diberi kesempatan untuk melakukan suatu kebijaksanaan sendiri." ${ }^{24}$ Hal tersebut sejalan dengan pendapat Rene Seerden dan Frits Stroink yang menyatakan bahwa

${ }^{22}$ Kuntjoro Purbopranoto, 1978, Sistem Pemerintahan Demokrasi, Cet. III, Eresco, Bandung, hlm. 1.

${ }^{23}$ Emanuel Sujadmiko, 2016, Bentuk Hukum Kerjasama Antar Daerah, Revka Petra Media, Surabaya, hlm. 17.

${ }^{24}$ Emanuel Sujadmiko, Bentuk Hukum Kerjasama Antar Daerah, Disertasi, Universitas Brawijaya, Malang. 
"In a decentralized state, some power is delegated to public authorities or agencies that have legal personality themselves and are not hierahchically subordinated to the central authority. Thy are self governing". ${ }^{25}$

Adanya pertentangan hukum dengan UU Pemerintahan Daerah mengenai kaitannya dengan energi dan sumber daya mineral, bidang sektoral menjadi urusan pemerintahan konkuren pilihan yang dibagi antara Pemerintah Pusat dan Daerah Provinsi dan Daerah Kabupaten/Kota. Berbeda dengan undang-undang sebelumnya, pengurusan izin usaha pertambangan yang dimiliki oleh pemerintah Kabupaten/Kota beralih menjadi kewenangan pemerintah provinsi dan pemerintah pusat, dan kemudian dengan lahirnya UU Penanaman Modal memberikan jaminan kewenangan pemerintah pusat menjadi sangat sentralisastik hal ini dikarenakan lahirnya undang undang penaman modal yang baru ini meletakan kewenangan penuh kepada pemerintah pusat.

Setidaknya terdapat 2 alasan tidak dilimpahkannya kewenangan perizinan dari pemerintah pusat kepada pemerintah daerah, yaitu ${ }^{26}$ :

a. Banyak terjadi penyimpangan penyimpangan hukum di bidang perizinan pada tataran pemerintahan Kabupaten/Kota.

b. Rendahnya jaminan kepastian hukum dan kepastian investasi untuk investor Adanya perubahan dalam sistem tatanan birokrasi dengan merumbah Undang - Undang Nomor 32 Tahun 2004 menjadi Undang Undang Nomor 23 Tahun 2014. Menerangkan bahwa kriteria Urusan Pemerintahan yang menjadi kewenangan Daerah Kabupaten/Kota adalah:

1) Urusan Pemerintahan yang lokasinya dalam Daerah kabupaten/kota;

2) Urusan Pemerintahan yang penggunanya dalam Daerah kabupaten/kota;

\section{${ }^{25}$ Ibid.}

${ }^{26}$ Rizkyana Zaffrindra Putri dan Lita Tyesta A.L.W, "Kajian Politik Hukum tentang Perubahan Kewenangan Pemberian Izin Usaha Pertambangan Mineral dan Batubara", Jurnal Law Reform, Vol. 11, No. 2, 2015, hlm. 203. 
3) Urusan Pemerintahan yang manfaat atau dampak negatifnya hanya dalam Daerah kabupaten/kota; dan/atau

4) Urusan Pemerintahan yang penggunaan sumber dayanya lebih efisien apabila dilakukan oleh Daerah kabupaten/kota.

Sedangkan pada Pasal 14 ayat (1) Undang Undang Nomor 23 Tahun 2014 tentang Pemerintahan Daerah, Penyelenggaraan Urusan Pemerintahan bidang kehutanan, kelautan, serta energi dan sumber daya mineral dibagi antara Pemerintah Pusat dan Daerah provinsi. Akan tetapi dengan lahirnya kewenangan perizinan yang setralistik dengan tidak meletakan kewenagan baik provinsi menunjukan adanya perguasaan yang besar yang nanti dapat menimbulkan kesewenang wenagan hukum.

Dengan tidak dilibatkanya pemerintah provinsi atau kabupaten akan memberikan dampak tidak adanya pengawasan kegiatan usaha, keterlambatan pengaturan maupun penurunan pajak daerah tempat usaha di jalankan. Sehingga tata laksana pengaturan di Undang-Undang yang menyangkut kewenangan Gubernur dan Bupati/Walikota menjadi tidak berfungsi karena meletakan keweangan sepenuhnya kepada pemerintah pusat. ${ }^{27}$

Setidaknya ada tiga dasar pertimbangan yang perlu mendapat perhatian yaitu secara filosofis, yuridis dan sosiologis. Secara filosofis, mengandung ketentuan-ketentuan yang belum sejalan konstitusi yang melukiskan berjalannya suatu negara, antara lain, karena bersifat belum adanya sifat desentralisasi yang dituangkan dalam konstitusi dengan memberikan kewenangan seluas luasnya pemerintah daerah sesuai dengan amanah konstitusi yang dituangkan dalam Pasal 18 UUD NRI 1945. Secara yuridis, peraturan perundang undangan tersebut bertentang dengan prinsip hukum Lex Superior derogat Legi Inferior dan bertentangan dengan UU Nomor 23 Tahun

${ }^{27}$ Lilis Supriatin dan Suwari Akhmaddhian, "Kewenangan Perizinan Usaha Pertambangan Pasca Berlakunya Undang - Undang Pemerintah Daerah (Studi di Kabupaten Kuningan Provinsi Jawa Barat)", Jurnal Unifikasi, Vol. 04, No. 02, Juli, 2017, hlm. 74. 
2014 dan undang - undang sektoral lainnya. Secara sosiologis, sudah tidak sesuai lagi dengan perkembangan dan tuntutan masyarakat sebagai bagian dalam pergaulan global yang selalu ingin dilibatkan serta menghendaki adanya kewenangan daerah yang mampu menampung dan menjawab aspirasi untuk menghendaki adanya perubahan di daerah tersebut. ${ }^{28}$

\section{Penutup}

RUU Mineral dan Batubara ini bermaksud untuk memangkas birokrasi yang berbelit-belit dan bermaksud untuk menyelesaikan persoalan hiperregulasi yang terjadi di Indonesia. RUU Mineral dan Batubara yang mengatur sentralisasi perizinan di mana perizinan mutlak menjadi kewenangan pemerintah pusat ini jelas bertentangan dengan prinsip Lex Superior derogat Legi Inferior, di mana prinsip ini menyatakan bahwa setiap peraturan perundang - undangan yang lebih tinggi mengesampingkan peraturan perundang - undangan yang lebih rendah. Pertentangan dapat dilihat dari amanah Pasal 18 UUD NRI Tahun 1945, yang merupakan landasan yang kuat untuk menyelenggarakan sistem desentralisasi atau Otonomi Daerah. Selain itu, RUU ini juga bertentangan dengan UU Pemerintah Daerah. Pada tahun 2016 perizinan IUP dialihkan dari pemerintah kabupaten/kota ke tangan pemerinah provinsi. Namun, di dalam RUU Mineral dan Batubara, kewenangan ditarik ke pemerintah pusat di bawah kekuasaan Presiden.

Ketidakkepercayaan pemerintah pusat terhadap pemerintah daerah, disebabkan adanya penyimpangan hukum di bidang perizinan pada tataran pemerintahan Kabupaten/Kota serta rendahnya jaminan kepastian hukum dan kepastian investasi untuk investor. Perubahan sistem tatanan perizinan yang sentralistik dengan tidak dilibatkanya pemerintah provinsi atau kabupaten akan memberikan dampak tidak adanya pengawasan kegiatan usaha, keterlambatan pengaturan maupun penurunan pajak daerah tempat usaha dijalankan, sehingga

${ }^{28}$ Agus Ngadino, "Orang Bangsa Indonesia Asli dalam Perspektif Hukum Kewarganegaraan”, Jurnal Simbur Cahaya, No. 38, Tahun XIII, Januari, 2009. 
Tata laksana pengaturan di Undang - Undang yang menyangkut kewenangan Gubernur dan Bupati/Walikota menjadi tidak berfungsi karena meletakkan kewenangan sepenuhnya kepada pemerintah pusat.

\section{Daftar Pustaka}

\section{Buku}

Atmosudirjo, Prajudi, 1983, Hukum Administrasi Negara, Ghalia Indonesia, Jakarta.

AZ, Lukman Santoso, 2015, Hukum Pemerintahan Daerah Mengurai Problemetika Pemekaran Daerah Pasca Reformasi di Indonesia, Pustaka Pelajar, Yogyakarta.

F.B.A, K.C Wheare, 1975, Modern Constitution, Oxford University Pers, London.

Hadjon, Philipus M dan Tatiek Sri Djatmiati, 2016, Argumen Hukum, Cet. VII, Gadjah Mada University Press, Yogyakarta.

Gadjong, Agussalim Andi, 2007, Pemerintahan Daerah Kajian Politik dan Hukum, Penerbit Ghalia Indonesia, Bogor.

Ibrahim, Johnny, 2010, Teori dan Metodologi Penelitian Hukum Normatif, Banyumedia, Malang.

Marzuki, Peter Mahmud, 2005, Penelitian Hukum, Edisi Revisi, Kencana, Jakarta.

Purbopranoto, Kuntjoro, 1978, Sistem Pemerintahan Demokrasi, Cet. III, Eresco, Bandung.

Sirajudin dan Winardi, 2015, Dasar - Dasar Hukum Tata Negara, Setara Pers, Malang.

Spelt, N.M dan J.B.J.M Ten Berge, Pengantar Hukum Perizinan, disunting oleh Philipus M Hadjon, 1993, Yuridika, Surabaya.

Sujadmiko, Emanuel, 2016, Bentuk Hukum Kerjasama Antar Daerah, Revka Petra Media, Surabaya.

Sunarno, Siswanto, 2006, Hukum Pemerintahan Daerah di Indonesia, Sinar Grafika, Jakarta.

\section{Artikel Jurnal}

Luhukay, Roni Sulistyanto, "Fungsi Rancangan Undang - Undang Omnibus Law Cipta Lapangan Kerja dalam Percepatan Pertumbuhan Ekonomi”, Jurnal Meta Yuridis, Vol. 3, No. 1, 2020. 
Luhukay, Roni Sulistyanto, "Karakteristik Tanggung Gugat Perusahaan Terhadap Lingkungan Dalam Menciptakan Kesejateraan Rakyat", Junal Meta Yuridis, Vol. 2, No. 1, 2009.

Luhukay, Roni Sulistyanto, “Tanggung Jawab PT Freeport Indonesia terhadap Penanganan Kerusakan Lingkungan Akibat Pertambangan di Kabupaten Mimika Papua", Lex Et Societatis, Vol. IV, No. 2, Maret, 2016.

Luhukay, Roni Sulistyanto, "Indenpendensi Kekuasaan Kehakiman Pasca Amandemen UUD 1945 dan Relevansinya Bagi Penegakan Hukum Berkeadilan”, Jurnal Jurisprudentie, Vol. 6, No. 1, Juni, 2019.

Luhukay, Roni Sulistyanto dan Abdul Kodir Jailani, "Penataan Sistem Peraturan Perundang-Undangan Dalam Mendukung Pengutan Konstitusi Ekonomi Indonesia", Jurnal Jatiswara, Vol. 34, No. 2, Juli, 2019.

Ngadino, Agus, "Orang Bangsa Indonesia Asli dalam Perspektif Hukum Kewarganegaraan”, Simbur Cahaya, No. 38, Tahun XIII, Januari, 2009.

Supriatin, Lilis dan Suwari Akhmaddhian, "Kewenangan Perizinan Usaha Pertambangan Pasca Berlakunya Undang - Undang Pemerintah Daerah (Studi di Kabupaten Kuningan Provinsi Jawa Barat)", Jurnal Unifikasi, Vol. 04, No. 02, Juli, 2017.

Zaffrindra, Rizkyana Putri dan Lita Tyesta A.L.W, "Kajian Politik Hukum tentang Perubahan Kewenangan Pemberian Izin Usaha Pertambangan Mineral dan Batubara", Jurnal Law Reform, Vol. 11, No. 2, 2015.

\section{Hasil Penelitian/Tugas Akhir}

Emanuel Sujadmiko, Bentuk Hukum Kerjasama Antar Daerah, Disertasi, Universitas Brawijaya, Malang.

Pudjiastuti, Lilik, 2013, Prinsip Hukum Pengaturan Perizinan Kefarmasian, Disertasi, Fakultas Hukum, Universitas Airlangga.

\section{Internet}

Kumparan, Dua Ribu Orang Gelar Sidang Rakyat, Tuntut Pembatalan UU Menerba, http://M.Kumparan.Com/Kumparannews/2-Ribu-Orang-GelarSidang-Rakyat-Tuntut-Pembatalan-Uu-Minerba-1tvivvmc0ih, diakses tanggal 15 Juni 2020.

OECD, Reviews of Regulatory Reform, Government Capacity to Assure High Quality Regulation, http://www.oecd.org/regreform/indonesia-2012review.htm, diakses tanggal 1 Maret 2020. 